\title{
Keterampilan Pemecahan Masalah Berbasis Model Experiential Learning
}

\author{
Tuti Hendriyani ${ }^{1}$, Carolina Ligya Radjah ${ }^{1}$, Arbin Janu Setiyowati ${ }^{1}$ \\ ${ }^{1}$ Bimbingan dan Konseling-Universitas Negeri Malang
}

\section{INFO ARTIKEL}

\section{Riwayat Artikel:}

Diterima: 19-09-2019

Disetujui: 10-03-2020

Kata kunci:
problem solving skills;
experiential learning model;
keterampilan pemecahan masalah;
model experiential learning

\author{
Alamat Korespondensi: \\ Tuti Hendriyani \\ Bimbingan dan Konseling \\ Universitas Negeri Malang \\ Jalan Semarang 5 Malang \\ E-mail: tuti12001131@gmail.com
}

\begin{abstract}
ABSTRAK
Abstract: This study aims to produce guidance products that have acceptance criteria. The type of research used is development using the research design of Borg and Gall. The stages used in this research are information gathering, planning, initial field testing, developing the initial product format, product revision, main field testing, and product revision or refining the main field test results. The data obtained in the form of quantitative data with the gregory model interrater agreement. The subjects in the field test consisted of two BK experts, two media experts, and two potential product users. The assessment conducted by the expert refers to the criteria for product acceptance which includes aspects of accuracy, aspects of usability, and aspects of eligibility. Based on the results of the field test the assessment results obtained from BK experts have a validity index of 0.73 which is categorized as "high", the assessment of media experts is 1.00 which is categorized as "very high", and from potential users that is 1.00 which is categorized as "very high ", so it can be concluded that the guidelines developed meet the product acceptance criteria.

Abstrak: Penelitian ini bertujuan menghasilkan produk panduan yang memiliki kriteria keberterimaan. Jenis penelitian yang digunakan adalah pengembangan menggunakan rancangan penelitian Borg and Gall. Tahapan yang digunakan dalam penelitian ini adalah pengumpulan informasi, perencanaan, uji lapangan awal, pengembangan format produk awal, revisi produk, uji lapangan utama, dan revisi produk atau penyempurnaan produk hasil uji lapangan utama. Data yang diperoleh berupa data kuantitatif dengan interrater agreement model gregory. Subjek dalam uji lapangan terdiri dari dua ahli BK, dua ahli media, dan dua calon pengguna produk. Penilaian yang dilakukan ahli mengacu pada krtiteria keberterimaan produk yang mencakup aspek ketepatan, aspek kegunaan, dan aspek kelayakan. Berdasarkan hasil uji lapangan diperoleh hasil penilaian dari ahli BK memiliki indeks validitas sebesar 0,73 yang dikategorikan "tinggi", penilaian dari ahli media yaitu 1,00 yang dikategorikan "sangat tinggi", dan dari calon pengguna yaitu 1,00 yang dikategorikan "sangat tinggi" sehingga dapat disimpulkan bahwa panduan yang dikembangkan memenuhi kriteria keberterimaan produk.
\end{abstract}

Keterampilan pemecahan masalah (problem solving skill) berada dalam ranah softskill (Utami, 2011). Pada dasarnya tiap individu memiliki keterampilan pemecahan masalah yang digunakan untuk menghadapi dan memecahkan masalah. Artinya, individu dapat menggunakan kemampuan yang ada dalam diri individu untuk mengidentifikasi masalah berdasarkan fakta dan informasi yang digunakan untuk membantu individu memperjelas situasi permasalahannya, serta melakukan langkah untuk menyusun berbagai alternatif dan menentukan solusi pemecahan masalah yang tepat. Adanya pemahaman terhadap masalah yang sedang dihadapi dapat mendorong proses kognitif dalam mencari solusi pemecahan masalah. Sesuai dengan pendapat (Nayazik, 2017) bahwa pemecahan masalah merupakan bagian dari kegiatan berpikir yang terjadi di dalam kehidupan.

Permasalahan dapat terjadi dalam berbagai segi aspek kehidupan yang dapat dialami tiap individu, seperti orang dewasa dan remaja. Menurut (Hurlock, 1980) masa remaja dikategorikan sebagai usia bermasalah. Pada masa remaja terjadi suatu proses perkembangan antara masa kanak-kanak dan masa dewasa yang ditandai oleh perubahan secara fisik, kognitif, dan sosio-emosional. Pada masa remaja awal terjadi adanya perubahan perkembangan emosional sehingga menimbulkan pergolakan emosi yang ditandai dengan munculnya berbagai masalah yang terjadi pada remaja. Masalah terjadi karena adanya masa storm and stress yang penuh gejolak, konflik, dan perubahan suasana hati pada remaja awal (Hall dalam Santrock, 2016). 
Berdasarkan hasil studi pendahuluan dengan pemberian skala keterampilan pemecahan masalah di SMPN 15 Malang sebanyak 95 menunjukkan bahwa terdapat 36 siswa atau sebanyak 37,89\% memiliki keterampilan pemecahan masalah pada kategori tinggi, 26 siswa atau sebanyak $27,37 \%$ memiliki keterampilan pemecahan masalah pada kategori sedang, dan 33 siswa atau sebanyak 34,74\% memiliki keterampilan pemecahan masalah pada kategori rendah. Data lain dari Komisi Perlindungan Anak Indonesia (KPAI) selama tahun 2012 telah terjadi tawuran siswa SMP sebanyak 147 kasus. Berdasarkan beberapa fenomena di atas menunjukkan adanya ketidakmampuan remaja dalam memecahkan masalah yang menimbulkan perilaku menyimpang. Oleh karena itu, perlunya keterampilan pemecahan masalah dimiliki oleh remaja untuk menghadapi dan memecahkan masalah secara mandiri agar terhindar dari perilaku yang menyimpang.

Individu dapat dikatakan memiliki keterampilan pemecahan masalah jika mampu memecahkan masalah dengan tepat dan sistematis seperti memiliki kemampuan mengidentifikasi masalah yang dihadapi, mampu mencari solusi berdasarkan identifikasi masalah, mengidentifikasi hambatan pada solusi yang telah dibuat, memilih solusi yang tepat, mencoba menerapkan solusi yang dipilih dalam pemecahan masalah, dan melakukan evaluasi solusi (Forgan, 2002) sehingga keterampilan pemecahan masalah perlu dilatihkan secara sistematis dan terstruktur agar siswa mampu menyelesaikan permasalahan. Oleh karena itu, guru BK dapat memberikan pelatihan yang dapat membantu siswa memecahkan masalah. Sesuai dengan pernyataan Jonassen dalam (Yaumi, 2012) bahwa keterampilan pemecahan masalah (problem solving skill) merupakan bagian penting yang dapat diajarkan atau dilatihkan di sekolah. Adapun penelitian yang relevan dengan pelatihan keterampilan pemecahan masalah yaitu penelitian (Surur, Triyono, \& Handarini, 2016) menunjukkan bahwa keterampilan pemecahan masalah (problem solving skill) secara efektif dapat ditingkatkan menggunakan teknik problem solving strategy pada siswa SMP. Hasil yang diperoleh secara umum problem solving strategy memberikan pengaruh untuk meningkatkan keterampilan pemecahkan masalah (problem solving skill) siswa SMP.

Berdasarkan hasil penelitian terdahulu tentang keterampilan pemecahan masalah (problem solving skill), maka dapat disimpulkan bahwa keterampilan pemecahan masalah dapat dilatihkan pada siswa SMP. Penelitian ini menggunakan model experiential learning sebagai metode dalam memberikan pelatihan keterampilan pemecahan masalah pada siswa SMP yang disusun dalam bentuk panduan. Panduan pelatihan keterampilan pemecahan masalah berbasis model experiential learning menggunakan pengalaman nyata berupa permasalahan yang dialami siswa sebagai topik dalam memberikan materi pelatihan yang dilakukan oleh guru BK. Model experiential learning memiliki relevansi dalam pelatihan keterampilan pemecahan masalah karena experiential learning adalah suatu model yang mengutamakan pengalaman nyata sebagai objek belajar siswa (Kolb, 1984). Pengalaman nyata yang dimiliki siswa dapat berupa permasalahan yang pernah dialami sehingga permasalahan tersebut dapat dijadikan sebagai objek belajar siswa dalam melatih keterampilan pemecahan masalah.

Kegiatan pelatihan dengan experiential learning mencakup empat tahapan yang digunakan adalah pengalaman nyata, observasi refleksi, abstrak konseptualisasi, dan aktif eksperimentasi (Kolb, 1984). Berdasarkan siklus pada experiential learning siswa dapat memahami dan mentransformasikan pengalaman yang diperoleh selama pembelajaran sehingga siswa dapat menerapkan keterampilan pemecahan masalah pada situasi kehidupan. Hal ini senada dengan temuan (Sutirman, Muhyadi, \& Surjono, 2018) experiential learning melibatkan siswa dalam berpikir kritis, memecahkan masalah, dan mengaplikasikan keterampilan dalam situasi yang baru. Adapun tujuan akhir dari intervensi yang diberikan ini adalah agar subjek memiliki transfer of learning yang dihasilkan dari pengalaman-pengalaman individu secara langsung dalam keterampilan pemecahan masalah. Hal ini diperkuat dengan pernyataan Luckmann (dalam Moore, Boyd, \& Dooley, 2010) bahwa experiential learning merupakan suatu proses di mana siswa membangun pengetahuan, keterampilan, dan nilai dari pengalaman secara langsung. Panduan ini merupakan pedoman bagi guru BK dalam membantu siswa untuk mengembangkan pengetahuan dalam melatih keterampilan pemecahan masalah (problem solving skill) agar siswa mampu mengentaskan masalah secara tepat, sehingga siswa tidak selalu bergantung pada bantuan yang diberikan orang lain.

\section{METODE}

Penggunaan metode dalam penelitian ini yaitu menggunakan metode pengambangan (Borg \& Gall, 2003) Tahapan pengembangan yang digunakan mencakup enam tahapan, yaitu pengumpulan informasi, rencana pembuatan panduan, mengembangkan produk, uji lapangan awal, revisi uji lapangan awal, dan uji lapangan utama. Peneliti menggunakan instrumen penelitian yaitu wawancara, skala keterampilan pemecahan masalah, angket kebutuhan guru BK, dan instrumen penilaian panduan. Penilaian yang dilakukan ahli mengacu pada kriteria keberterimaan produk yang mencakup aspek ketepatan, aspek kegunaan, dan aspek kelayakan. Adapun subjek ahli dalam penelitian ini, terdiri dua ahli BK, dua ahli media, dua guru BK sebagai calon uji pengguna produk. Data dalam penelitian yang dikembangkan berupa kuantitatif dengan interrater agreement model Gregory. Kategori indeks validasi panduan mengacu pada pengklasifikasian validitas yang dikemukakan oleh Guilford (Gregorry, 2013).

\section{HASIL}

Produk yang dihasilkan dalam penelitian ini yaitu panduan pelatihan keterampilan pemecahan masalah dengan model experiential learning yang memenuhi aspek keberterimaan produk. Panduan yang dikembangkan memiliki kerangka isi yang terdiri dari Bab I, II, dan III. Bagian isi panduan terdiri dari Bab I menyajikan pendahuluan yang memuat penjelasan atas rasional dan tujuan pelatihan serta materi atas penggunaan panduan pelatihan keterampilan pemecahan masalah dengan model 
experiential learning. Bab II berupa petunjuk pelaksanaan, terdiri dari petunjuk pelaksanaan pelatihan, pengguna panduan, sasaran pelatihan, penggunaan instrumen pelatihan, strategi intervensi, dan penentuan jadwal pelatihan. Bab III berupa prosedur pelaksanaan yang terdiri dari skenario pelakasanaan. Pada pelaksanaan pelatihan untuk meningkatkan keterampilan pemecahan masalah berdasarkan tahapan dalam model experiential learning yang digunakan dalam pelatihan ini. Produk yang dikembangkan memenuhi aspek keberterimaan produk yang meliputi aspek ketepatan, kegunaan, dan kelayakan. Adapun hasil penilaian yang dilakukan oleh uji ahli sebagai berikut.

\section{Tabel 1. Hasil Penilaian Uji Ahli}

\begin{tabular}{|c|c|c|c|c|}
\hline \multirow[t]{2}{*}{ No } & \multirow{2}{*}{$\begin{array}{c}\text { Aspek Keberterimaan } \\
\text { Produk }\end{array}$} & \multicolumn{3}{|c|}{ Uji Ahli } \\
\hline & & Ahli BK & Ahli Media & Calon Pengguna Produk \\
\hline 1. & Ketepatan & $\begin{array}{l}\text { Terdapat enam butir penilaian yang } \\
\text { memiliki kategori kesepakatan } \\
\text { berada pada kolom D saebanyak } \\
\text { empat butir dan dua butir lainnya } \\
\text { berada pada kolom B dengan hasil } \\
\text { nilai indeks uji ahli sebesar } 0,66\end{array}$ & $\begin{array}{l}\text { Terdapat enam butir penilaian yang } \\
\text { memiliki kategori kesepakatan } \\
\text { berada pada kolom D dengan hasil } \\
\text { nilai indeks uji ahli sebesar } 1,00\end{array}$ & $\begin{array}{l}\text { Terdapat } 12 \text { butir penilaian yang } \\
\text { memiliki kategori kesepakatan } \\
\text { berada pada kolom D dengan } \\
\text { hasil nilai indeks uji ahli sebesar } \\
1,00\end{array}$ \\
\hline 2. & Kegunaan & $\begin{array}{l}\text { Terdapat tiga butir penilaian yang } \\
\text { memiliki kategori kesepakatan } \\
\text { berada pada kolom D dengan hasil } \\
\text { niai indeks uji ahli sebesar } 1,00\end{array}$ & $\begin{array}{l}\text { Terdapat enam butir penilaian yang } \\
\text { memiliki kategori kesepakatan } \\
\text { berada pada kolom D dengan hasil } \\
\text { nilai indeks uji ahli sebesar } 1,00\end{array}$ & $\begin{array}{l}\text { Terdapat Sembilan butir } \\
\text { penilaian yang memiliki } \\
\text { kategori kesepakatan berada } \\
\text { pada kolom D dengan hasil nilai } \\
\text { indeks uji ahli sebesar } 1,00\end{array}$ \\
\hline 3. & Kelayakan & $\begin{array}{l}\text { Terdapat enam butir penilaian yang } \\
\text { memiliki kategori kesepakatan } \\
\text { berada pada kolom D saebanyak } \\
\text { empat butir dan dua butir lainnya } \\
\text { berada pada kolom B dengan hasil } \\
\text { nilai indeks uji ahli sebesar } 0,66\end{array}$ & $\begin{array}{l}\text { Terdapat delapan butir penilaian } \\
\text { yang memiliki kategori } \\
\text { kesepakatan berada pada kolom D } \\
\text { dengan hasil nilai indeks uji ahli } \\
\text { sebesar } 1,00\end{array}$ & $\begin{array}{l}\text { Terdapat Sembilan butir } \\
\text { penilaian yang memiliki } \\
\text { kategori kesepakatan berada } \\
\text { pada kolom D dengan hasil nilai } \\
\text { indeks uji ahli sebesar } 1,00\end{array}$ \\
\hline
\end{tabular}

Pada tabel di atas terdapat hasil indeks uji ahli BK pada aspek ketepatan sebesar 0,66 yang memiliki kategori validitas "tinggi", sedangkan hasil indeks uji ahli BK pada aspek kegunaan sebesar 1,00 yang memiliki kategori valitidas "sangat tinggi", dan hasil indeks uji ahli BK pada aspek kelayakan sebesar 0,66 yang memiliki kategori validitas "tinggi”. Selain itu, penilaian secara keseluruhan dari kedua ahli BK diperoleh hasil indeks uji ahli sebesar 0,73 yang memiliki kategori validitas "tinggi". Berdasarkan hasil indeks uji ahli menunjukkan bahwa panduan keterampilan pemecahan masalah (problem solving skill) berbasis model experiential learning layak digunakan oleh guru BK.

Pada hasil uji media diperoleh hasil indeks uji ahli media pada aspek ketepatan sebesar 1,00 yang memiliki kategori validitas "sangat tinggi", sedangkan hasil indeks uji ahli media pada aspek kegunaan sebesar 1,00 yang memiliki kategori valitidas "sangat tinggi", dan hasil indeks uji ahli media pada aspek kelayakan sebesar 1,00 yang memiliki kategori validitas "sangat tinggi". Selain itu, penilaian secara keseluruhan dari kedua ahli media diperoleh hasil indeks uji ahli sebesar 1,00 yang memiliki kategori validitas "sangat tinggi". Berdasarkan hasil indeks uji ahli menunjukan bahwa panduan keterampilan pemecahan masalah (problem solving skill) berbasis model experiential learning layak digunakan sebagai panduan oleh guru BK.

Pada hasil uji calon pengguna diperoleh hasil indeks uji calon pengguna pada aspek ketepatan sebesar 1,00 yang memiliki kategori validitas "sangat tinggi", sedangkan hasil indeks uji ahli pada aspek kegunaan sebesar 1,00 yang memiliki kategori valitidas "sangat tinggi", dan hasil indeks uji ahli pada aspek kelayakan sebesar 1,00 yang memiliki kategori validitas "sangat tinggi". Selain itu, penilaian secara keseluruhan dari kedua calon pengguna diperoleh hasil indeks uji calon pengguna sebesar 1,00 yang memiliki kategori validitas "sangat tinggi". Berdasarkan hasil indeks uji calon pengguna menunjukan bahwa panduan keterampilan pemecahan masalah (problem solving skill) berbasis model experiential learning layak digunakan oleh guru BK.

\section{PEMBAHASAN}

Penelitian dan pengembangan yang telah dilakukan memberikan hasil berupa produk panduan keterampilan pemecahan masalah (problem solving skill) berbasis model experiential learning. Produk panduan yang dikembangkan telah memenuhi syarat keberterimaan produk. Produk panduan juga telah tervalidasi secara teoritis sesuai dengan hasil uji lapangan. Penilaian dari uji lapangan dilakukan agar produk yang dikembangkan memiliki nilai ketepatan, kegunaan, dan kelayakan. Hal ini sesuai dengan pernyataan (Widiasih, Permanasari, Riandi, \& Damayanti, 2018) bahwa validasi panduan yang dilakukan oleh ahli bertujuan untuk memberikan penilaian dan menentukan kelayakan dari panduan yang telah dikembangkan. 
Adapun kajian yang dilakukan oleh ahli media mencakup aspek ketepatan, kegunaan, kelayakan produk sebagai panduan bagi guru BK. Bahan ajar atau panduan yang digunakan dalam pembelajaran diharapkan memiliki kualitas yang baik karena panduan yang digunakan dalam proses pembelajaran dapat memengaruhi kualitas guru dan kualitas siswa dalam proses pelaksanaanya (Kantun \& Budiawati, 2015). Oleh karena itu, peneliti melakukan penilaian ahli media sehingga produk memiliki kualitas dari aspek ketepatan, kegunaan, kelayakan produk dan dapat digunakan oleh guru BK.

Penilaian panduan pada aspek kegunaan yang diberikan oleh ahli media memiliki nilai validasi sangat tinggi karena panduan merupakan media pembelajaran yang memiliki nilai kegunaan bagi guru BK maupun siswa. Hal ini sesuai dengan hasil temuan (Sari \& Suswanto, 2017) bahwa media pembelajaran (bahan, alat, setiap orang, atau peristiwa) dapat digunakan untuk membantu siswa dengan menciptakan kondisi memungkinkan siswa dapat menerima pengetahuan dan keterampilan. Sehingga panduan keterampilan pemecahan masalah (problem solving skill) berbasis model experiential learning memenuhi syarat dalam aspek kegunaan produk.

Penilaian panduan pada aspek kelayakan yang diberikan oleh ahli media memiliki nilai validasi sangat tinggi karena produk yang dikembangkan memiliki kelayakan isi dan penyajian. Hal ini sesuai dengan (Harahap, Sari, Pane, \& Nuraini, 2019) penilaian produk berdasarkan BSNP mengacu pada kelayakan isi, bahasa, penyajian, dan kegrafikan, sehingga panduan pelatihan keterampilan pemecahan masalah (problem solving skill) dengan model experiential learning memenuhi syarat dalam aspek kelayakan produk. Berdasarkan hasil penilaian panduan pelatihan keterampilan pemecahan masalah (problem solving skill) berbasis model experiential learning yang dilakukan oleh kedua ahli media maka dapat disimpulkan bahwa panduan yang dikembangkan memenuhi kriteria keberterimaan pada aspek ketepatan, aspek kegunaan, dan aspek kelayakan produk.

Penilaian produk juga dilakukan oleh ahli BK. Penilaian panduan dilakukan pada tiap aspek keberterimaan produk telah memenuhi syarat dalam aspek ketepatan produk. Penilaian pada aspek ketepatan yang diberikan oleh ahli BK memiliki nilai validasi tinggi karena tahapan experiential learning yang digunakan dalam pelatihan ini tersusun secara berkesinambungan dengan tahapan keterampilan pemecahan masalah. Hal ini sesuai dengan pernyataan (Dernova, 2015) bahwa model experiential learning menyajikan dua proses pengalaman yang saling berhubungan dan menciptakan dua mode terkait transformasi pengalaman. Proses ini mencakup pengetahuan yang merupakan konsep, fakta dan informasi yang diperoleh dalam pendidikan formal dan pengalaman sebelumnya, serta adanya analisis pengetahuan yang mampu menciptakan pengalaman baru. Sehingga siswa dapat memperoleh pengalaman baru sesuai dengan tahapan ISOLVE pada model experiential learning. Sesuai dengan hasil temuan (Purwaningrum, 2011) experiential learning memiliki tahapan yang berkesinambungan sehingga memiliki aspek merasakan, menggambarkan, dan berpikir.

Penilaian panduan pada aspek kegunaan yang diberikan oleh ahli BK memiliki nilai validasi tinggi, sehingga panduan keterampilan pemecahan masalah (problem solving skill) berbasis model experiential learning memenuhi syarat dalam aspek kegunaan produk. Hal ini sesuai dengan bahwa pernyataan Jonassen (dalam Yaumi, 2012) bahwa keterampilan pemecahan masalah (problem solving skill) merupakan bagian penting yang dapat diajarkan atau dilatihkan di sekolah. Sehingga panduan memiliki nilai guna bagi guru BK dan siswa. Penilaian panduan pada aspek kelayakan yang diberikan oleh ahli BK memiliki nilai validasi tinggi karena panduan yang dikembangkan memenuhi kelayakan pada prosedur pelatihan. Hal ini sesuai dengan pernyataan Adam dalam (Barida, 2015) bahwa model experiential learning menyediakan prosedur dan arah pembelajaran yang tepat sehingga siswa dapat menerapkan pengalaman yang diperoleh pada waktu atau konteks yang tepat. Sehingga panduan yang dikembangkan memenuhi syarat dalam aspek kelayakan produk. Berdasarkan hasil penilaian panduan dari kedua ahli BK maka dapat disimpulkan bahwa panduan yang dikembangkan memenuhi kriteria keberterimaan pada aspek ketepatan, aspek kegunaan, dan aspek kelayakan produk.

Penilaian produk juga dilakukan oleh dua guru BK sebagai calon pengguna produk. Berdasarkan hasil penilaian panduan yang dilakukan oleh kedua calon pengguna panduan maka dapat disimpulkan bahwa panduan telah memenuhi kriteria keberterimaan pada aspek ketepatan, aspek kegunaan, dan aspek kelayakan produk. Panduan ini dapat memandu guru BK dalam memfasilitasi dan membantu siswa untuk mengembangkan pengetahuan dalam melatih keterampilan pemecahan masalah (problem solving skill) agar siswa mampu mengentaskan masalah secara tepat sehingga siswa tidak selalu bergantung pada bantuan yang diberikan orang lain.

Guru BK sebagai tenaga profesional yang memberikan layanan bantuan pada siswa dalam mengentaskan masalah yang dihadapi agar siswa dapat mencapai tugas perkembangannya. Hal ini sesuai pernyataan (Setiyowati, 2017) bahwa guru BK atau konselor merupakan tenaga profesional yang memiliki fungsi dalam peningkatan pengembangan karakter dan tugas perkembangan siswa. Berdasarkan pernyataan tersebut guru BK memiliki peran dalam membantu siswa agar dapat mencapai tugas perkembangannya. Salah satu aspek perkembangan pribadi sosial yaitu kemampuan menyelesaikan masalah individu. Hal ini sesuai dengan Standar Kompetensi Kemandirian Peserta Didik (SKKPD) dalam sepuluh aspek perkembangan siswa SMP (Kemendikbud, 2016). Salah satu aspek perkembangan siswa SMP yang sesuai dengan keterampilan pemecahan masalah yaitu aspek kematangan intelektual yang menunjukan tugas perkembangan siswa SMP dalam mengembangkan pengetahuan dan keterampilan yang dimiliki sesuai dengan kebutuhannya. Hal ini sesuai dengan Joni (Radjah, 2016) bahwa tugas guru BK membantu siswa agar mandiri dan pontesi yang dimilikinya berkembang, serta mampu mengambil keputusan untuk mencapai tujuan hidup. 


\section{SIMPULAN}

Simpulan hasil pengembangan ini yaitu menghasilkan panduan keterampilan pemecahan masalah (problem solving skill) berbasis model experiential learning yang memenuhi kriteria keberterimaan produk yang meliputi ketepatan produk, kegunaan produk, dan kelayakan produk. Berdasarkan hasil penelitian di atas, adapun saran yang ditujukan bagi guru BK dan peneliti selanjutnya. Pertama, bagi guru BK. Guru BK dapat memahami prosedur pelaksanaan pelatihan dalam panduan ini agar kegiatan pelatihan yang dilaksanakan dapat berjalan lancar serta meminimalisir terjadinya kendala di lapangan dan guru BK dapat menambah referensi kegiatan sesuai dengan model experienatial learning yang digunakan sebagai model dalam kegiatan pelatihan. Kedua, bagi peneliti selanjutnya. Peneliti dapat melakukan uji efektivitas produk secara operasional dengan melakukan penelitian eksperimen.

\section{DAFTAR RUJUKAN}

Barida, M. (2015). Keefektifan Pelatihan Metakognisi Melalui Model Experiential Learning untuk Meningkatkan Kinerja Konselor Dalam Layanan Konseling. Tesis tidak diterbitkan. Universitas Negeri Malang, Malang.

Borg, W. R., \& Gall, M. D. (2003). Educational Research (Seventh edition). Educational Research: An introduction.

Dernova, M. (2015). Experiential Learning Theory as One of The Foundations of Adult Learning Practice Worldwide. Comparative Professional Pedagogy, 5(2), 52-57. https://doi.org/10.1515/rpp-2015-0040

Forgan, J. (2002). Using Bibliotherapy to Teach Problem Solving. Journal Invention in Socialand Clinic, 38(2), 75-82. https://doi.org/10.1177/10534512020380020201

Gregorry, R. (2013). Psychological Testing: History, Principles, and Applications (7th Ed). Boston: Allyn and Bacon.

Harahap, J., Sari, N., Pane, S. A.-Y., \& Nuraini, N. (2019). Analisis Kelayakan Buku Panduan Praktikum Kimia Kelas XII Semeter II Berdasarkan BSNP Sesuai Kurikulum 2013. Talenta Conference Series: Science and Technology (ST), 2(1), 194-198. https://doi.org/10.32734/st.v2i1.341

Hurlock, E. (1980). Psikologi Perkembangan. Jakarta: Erlangga.

Kantun, S., \& Budiawati, Y. S. R. (2015). Analisis Tingkat Kelayakan Bahan Ajar Ekonomi yang Digunakan oleh Guru di SMA Negeri 4 Jember. Jurnal Pendidikan Ekonomi, 9(2), 129-146.

Kemendikbud. (2016). Panduan Operasional Penyelenggaraan Bimbingan dan Konseling Sekolah Menengah Pertama (SMP). Jakarta: Kementerian Pendidikan dan Kebudayaan Direktorat Jenderal Guru dan Tenaga Kependidikan.

Moore, C., Boyd, B. L., \& Dooley, K. E. (2010). The Effects of Experiential Learning with an Emphasis on Reflective Writing on Deep-Level Processing of Leadership Students. Journal of Leadership Education, 9(1), 36-52. https://doi.org/10.12806/v9/i1/rf3

Nayazik, A. (2017). Pembentukan Keterampilan Pemecahan Masalah Melalui Model IDEAL Problem Solving dengan Teori Pemrosesan Informasi. Kreano: Jurnal Matematika Kreatif-Inovatif, 8(2), 182-190. https://doi.org/10.15294/kreano.v8i2.7163

Radjah, C. (2016). Keterampilan Konseling Berbasis Metakognisi. Jurnal Kajian Bimbingan dan Konseling, 1(3), 90-94. https://doi.org/10.17977/um001v1i32016p090

Sari, H. V., \& Suswanto, H. (2017). Pengembangan Media Pembelajaran Berbasis Web untuk Mengukur Hasil Komputer Jaringan Dasar Program Keahlian Teknik Komputer dan Jaringan. Jurnal Penelitian: Teori, Penelitian, dan Pengembangan, 2(7), 1008-1016.

Setiyowati, A. J. (2017). Understanding Profession Identity of Junior High School Counselor in Malang City. 118, 816-823. https://doi.org/10.2991/icset-17.2017.133

Surur, M., Triyono., \& Handarini, D. M. (2016). Keefektifan Problem Solving Strategy untuk Meningkatkan Keterampilan Memecahkan Masalah pada Siswa SMP. Jurnal Pendidikan: Teori, Penelitian, dan Pengembangan, 1(11), 2211-2219.

Sutirman., Muhyadi., \& Surjono, H. D. (2018). Integration of Strategy Experiential Learning in E-Module of Electronic Records Management. Jurnal Pendidikan Vokasi, 7(3), 275-287. https://doi.org/10.21831/jpv.v7i3.12812

Utami, N. W. (2011). Pengembangan Panduan Pelatihan Keterampilan Pemecahan Masalah dengan Cinema Education untuk Siswa SMP. Tesis tidak diterbitkan. Universitas Negeri Malang, Malang.

Widiasih, Permanasari, A., Riandi, \& Damayanti, T. (2018). The Profile of Problem-Solving Ability of Students of Distance Education in Science Learning. Journal of Physics: Conference Series, 1013(1). https://doi.org/10.1088/17426596/1013/1/012081

Yaumi, M. (2012). Pembelajaran Berbasis Multiple Intelligences. Jakarta: Dian Rakyat. 